\title{
EFFECT OF NITROGEN FERTILIZER ON GROWTH, FLOWERING, FRUITING AND NODULATION OF THREE VARIETIES OF COMMON BEAN IN THE ARID REGION OF AÏN NAGA (BISKRA, ALGERIA)
}

\author{
L.M. MANSOURI ${ }^{1}$, A. KHELOUFI ${ }^{1 *}$, R. BELATRECHE ${ }^{1}$ \\ N. HELEILI ${ }^{2}$, Z.F. BOUKHATEM ${ }^{3}$
}

*E-mail: abdenour.kheloufi@yahoo.fr

Received: Mar. 07, 2020. Revised: Mar. 27, 2020. Accepted: Apr. 10, 2020. Published online: June 5, 2020

\begin{abstract}
Field experiments were conducted to investigate the response of common bean (Phaseolus vulgaris L.) to nitrogen fertilizer. The main factor included the fertilizer (Granular Urea $46 \% \mathrm{~N}$ ), was made up of two levels: no fertilization (0 kg/plot: control) and fertilization $(0.4 \mathrm{~kg} / \mathrm{plot})$, while the secondary factor was the variety (three varieties of common bean: Djedida, Nelson and Jalila). The experimental design was a randomized complete block design with split plot arrangement and replicated four times. The effect of fertilization was evaluated during two development stages (flowering and fruiting) for each variety and this on the total dry biomass, the length of the aerial and root parts, as well as on the number of secondary roots. On the other hand, the combined effect of fertilization and variety was studied on some yield
\end{abstract}

parameters per plant, such as the number of flowers, pods, seeds and the harvest index. In addition, the number of nodules at the end of seed maturation was evaluated. The results indicated that the nitrogen fertilizer application significantly reduced the root length, the number of nodules and secondary roots in most of the common bean varieties. However, fertilizer application significantly increased dry matter in both flowering and fruiting stages, for the three studied varieties. Pod number per plant and seed yield was increased by the application of $\mathrm{N}$ fertilizer, depending on varieties and the parameters being measured. Djedida and Jalila varieties gave the best yield and can therefore be recommended to farmers. According to our results, the percentage of improvement by $\mathrm{N}$ fertilization on one parameter or another does not exceed an average of $20 \%$,

\footnotetext{
${ }^{1}$ Department of Ecology and Environment, University of Batna 2, Batna 05078, Algeria

2 Department of Veterinary Sciences, University of Batna 1, Batna 05000, Algeria

${ }^{3}$ Department of Biotechnology, University of Oran 1, 31000 Oran, Algeria
} 
compared to the control. Indeed, the effect of fertilization is positive and seems to increase the harvest index by $18 \%$ in Djedida and by $20 \%$ in Jalila, compared to non-fertilized plants. Unfertilized plants of the variety Nelson showed the highest ability to nodulate.

Keywords: agriculture; dry matter; crops; Fabaceae; Phaseolus vulgaris; yield.

\section{INTRODUCTION}

In order to obtain an optimal production yield in the current circumstances of climate change and land desertification, it is required to consider both soil fertility and the quality of the environment, by adopting suitable agricultural practices and techniques (Senyolo et al., 2018). However, the lack of knowledge about the real needs of the soil, in terms of fertilization, often leads to over-fertilization or under-fertilization which is the source of the decline in production yield (Jin et al., 2017). On the other hand, the long-term application of chemical fertilizers simultaneously affects the physicochemical and microbiological properties of the soil (Knap et al., 2010; Chakraborty et al., 2011; Li et al., 2015; Yin et al., 2019). This second entity is often ignored in fertilization practices when it not only guarantees the sustainable maintenance of soil fertility, but also better productivity (Lemanceau et al., 2015).

A change in the diversity and density of soil microorganisms reflects a deep change in soil fertility (Zhang et al., 2016; Bokhorst et al.,
2017). Indeed, nitrogen-fixing bacteria, whether free or associated in symbiotic relationship with species of the Fabaceae family, are components which are strongly involved in the biogeochemical cycle and the improvement of plant growth (Carranca, 2013; Souza et al., 2015). Generally, various types of organic, mineral or mixed amendments, as well as various cropping systems are practiced without prior consideration of the biological components of the soil (Larey and Angers, 2012). Hence, the importance of finding the right type of fertilization, as well as the interesting variety to guarantee optimal productivity, respectful of soil fertility and the functioning of this type of microbial communities (Smethurst, 2010).

Common beans (Phaseolus vulgaris L.), with their numerous varieties, are among the most consumed legumes, because of their moderate amount of calories and their richness in other nutritive substances (Choze et al., 2013; Baptista et al., 2017). Common bean is a crop of the small farmer, commonly grown under conditions of low soil fertility and with minimal technical inputs (Graham, 1981). Several researches have shown that the development and the productivity, as well as the quality of the pods and the seeds of common bean are strongly dependent on soil fertility (Otieno et al., 2009; Fernández-Luqueño et al., 2010; Turuko et al., 2014; Nassary et al., 2020). However, some researches have indicated that common bean is a legume that nodulates slightly or with 
difficulty, and therefore its cultivation requires a nitrogen fertilizer amendment (Fustec et al., 2010; Osdaghi et al., 2011; García-Garijo et al., 2014; Liu et al., 2018). In the same context, Nascente et al. (2017) found that common bean varieties react differently to mineral/nitrogen fertilization. In our previous study by Mansouri et al. (2019), we found that the seeds of P. vulgaris, Djedida var. were able to germinate under various concentration and types of salt, especially under high calcareous condition.

The main objective was to describe the evolution of plants of three varieties of common bean (Djedida, Nelson and Jalila), by amount of fertilizer adopted and this during two main periods (flowering and fruiting) and on some morphophysiological parameters related to yield in the arid region of Biskra (Algeria). A second objective was to assess the ability of nodulating in these three varieties.

\section{MATERIAL AND METHODS}

\section{Cultural site location}

This study was carried out during the 2019 growing season, in an agricultural exploitation at Aïn Naga, a city located in the arid region of Biskra (Southeast of the capital Algiers), in Algeria. Precisely, this site is located at the latitude of $34^{\circ} 43^{\prime} 12.37^{\prime \prime} \mathrm{N}$ and the longitude of $6^{\circ} 14^{\prime} 32.98^{\prime \prime} \mathrm{E}$, for an elevation of $23 \mathrm{~m}$. Biskra is located in the arid region, according to the De Martonne aridity index. According to climate date (1980-2019), the climate of Biskra is characterized by a very hot and dry summer with an average temperature of $43.5^{\circ} \mathrm{C}$ and an average relative humidity of $12 \%$. Winter is cold (average minimum temperature $4^{\circ} \mathrm{C}$ and average maximum relative humidity $89 \%$ ). Rainfall is rare and does not exceed 30 days a year.

The meteorological data prevailing, during the experimental period, are shown in Table 1. According to this table, the amount of precipitation is almost zero. These data were confirmed and supported in situ by recording a zero number of precipitations. These meteorological conditions, recorded during our study represented an advantage because heavy rains could disturb our experimental design, especially if the nitrogen fertilizer moved towards plots aiming to represent control (without fertilization).

The cultural site intended for this study $(15 \times 30 \mathrm{~m})$ has not been exploited for five years by any plant crops. The results of the soil analysis (at 25-30 cm depth), before the experiment, revealed a $\mathrm{pH}$ of $7.7 ; 0,119 \%$ Nitrogen $\left(\mathrm{NO}_{3}{ }^{-}\right)$; $182.8 \mathrm{mg} / \mathrm{kg}_{\text {soil }}$ Phosphorus $\left(\mathrm{P}_{2} \mathrm{O}_{5}\right)$ and $1.22 \mathrm{meq} / \mathrm{kg}_{\text {soil }}$ Potassium. The soil has a silty texture, with an electrical conductivity of $2.58 \mathrm{~ms} / \mathrm{cm}$. This high electrical conductivity interpreted by high soil salinity is due to the high concentration of calcium ions (20.3 meq/100 $\mathrm{g}_{\text {soil }}$ ), compared to $1.36 \mathrm{meq} / 100 \mathrm{~g}_{\text {soil }}$ of $\mathrm{Mg}^{+2}$, $1.18 \mathrm{meq} / 100 \mathrm{~g}_{\text {soil }}$ of $\mathrm{K}^{+}$and $1.25 \mathrm{meq} / 100$ $\mathrm{g}_{\text {soil }}$ of $\mathrm{Na}^{+}$. The soil has been classified as very calcareous with $53.1 \%$ of total $\mathrm{CaCO}_{3}$.

\section{Biological material}

This study focused on three varieties of common bean (Phaseolus vulgaris L.). These three varieties are the most dominant in the agriculture market and the most cultivated in the South of Algeria. The origin of these three varieties viz. Djedida, Nelson and 


\section{L.M. MANSOURI, A. KHELOUFI, R. BELATRECHE, N. HELEILI, Z.F. BOUKHATEM}

Jalila is Griffaton Producteur Grainier (France), distributed in Algeria by SARL Agroseed. The seeds of these three varieties were harvested in 2017 and only Djedida and Nelson have been treated with Thiram (a non-systemic fungicide).

We first evaluated the biometric characteristics of the seeds for each variety and the results are shown in
Table 2. According to the analysis of variance, there is a significant effect $(p<0.0001)$ of the variety on the 1000 -seed weight and on the seed size. According to Duncan Multiple Range Test, the classification, according to seed size, is as follows Djedida > Jalila > Nelson (Table 2, Fig. 1).

Table 1 - Climatic data during the experimental period

\begin{tabular}{clccc}
\hline \multirow{2}{*}{ Climatic parameters } & \multicolumn{3}{c}{ Months (Year 2019) } \\
\cline { 2 - 5 } & & October & November & December \\
\hline \multirow{2}{*}{ Precipitations } & Quantity (mm) & 0.51 & 8.38 & 2.28 \\
& Number of rainy days & 0 & 0 & 0 \\
\cline { 2 - 5 } Temperature $\left({ }^{\circ} \mathrm{C}\right)$ & Maximum & 29.6 & 20.4 & 20.3 \\
& Average & 24.3 & 15.8 & 15 \\
\cline { 2 - 5 } & Minimum & 18.9 & 10.7 & 10 \\
\hline \multicolumn{2}{c}{ Relative humidity (\%) } & 43 & 53.4 & 51.6 \\
\hline
\end{tabular}

Source: World Climate Data: Tutiempo (https://fr.tutiempo.net/climat/2019/ws-605250.html)

Table 2 - Seed characteristics of the three common bean used in the experience

\begin{tabular}{|c|c|c|c|c|c|}
\hline \multirow[b]{2}{*}{ Varieties } & \multirow{2}{*}{$\begin{array}{c}1000- \\
\text { seed } \\
\text { weight } \\
(g) \\
(n=4)\end{array}$} & \multicolumn{3}{|c|}{ Seed size $(n=50)$} & \multirow{2}{*}{$\begin{array}{c}\text { Seed } \\
\text { maturity } \\
\text { (days) }\end{array}$} \\
\hline & & $\begin{array}{l}\text { Seed length } \\
(\mathrm{mm})\end{array}$ & $\begin{array}{l}\text { Seed width } \\
(\mathrm{mm})\end{array}$ & $\begin{array}{l}\text { Seed thickness } \\
(\mathrm{mm})\end{array}$ & \\
\hline Djedida & $\begin{array}{l}283.6 \pm \\
2.00^{\mathrm{a}}\end{array}$ & $12.7 \pm 0.73^{\mathrm{a}}$ & $6.19 \pm 0.39^{a}$ & $5.29 \pm 0.44^{a}$ & $85-100$ \\
\hline Nelson & $\begin{array}{c}213.1 \pm \\
0.73^{\mathrm{c}}\end{array}$ & $11.4 \pm 0.66^{c}$ & $5.37 \pm 0.37^{c}$ & $4.68 \pm 0.49^{c}$ & $85-100$ \\
\hline Jalila & $\begin{array}{c}231,7 \pm \\
1.07^{\mathrm{b}}\end{array}$ & $11.9 \pm 0.80^{b}$ & $5.76 \pm 0.26^{b}$ & $5.26 \pm 0.25^{b}$ & $85-100$ \\
\hline $\begin{array}{l}\text { F of } \\
\text { Fisher }\end{array}$ & 2817.5 & 36.4 & 70.1 & 75.6 & - \\
\hline Probability & $<0.0001$ & $<0.0001$ & $<0.0001$ & $<0.0001$ & - \\
\hline
\end{tabular}

The same alphabet letters along the column indicates no significance difference (Duncan Multiple Range Test)

\section{Fertilization}

The nitrogen fertilizer was supplied in the form of $46 \%$ granulated urea, for the fertilized plots. It is a nitrogen fertilizer entirely in urea form. In the form of water-soluble granules, it provides a very rich nitrogen supply for crops with very good spreadability, due to its homogeneous and regular particle size (1.8 $\mathrm{mm}$ of average diameter). In the soil, urea must first be hydrolyzed to ammonia, to be fully usable by the plant. 


\section{PERFORMANCE OF COMMON BEAN UNDER NITROGEN FERTILIZATION}

Processing speed depends on soil temperature and humidity, for hours or even days after spreading. Its use requires special attention because of the phenomenon of volatilization of ammonia in the atmosphere.

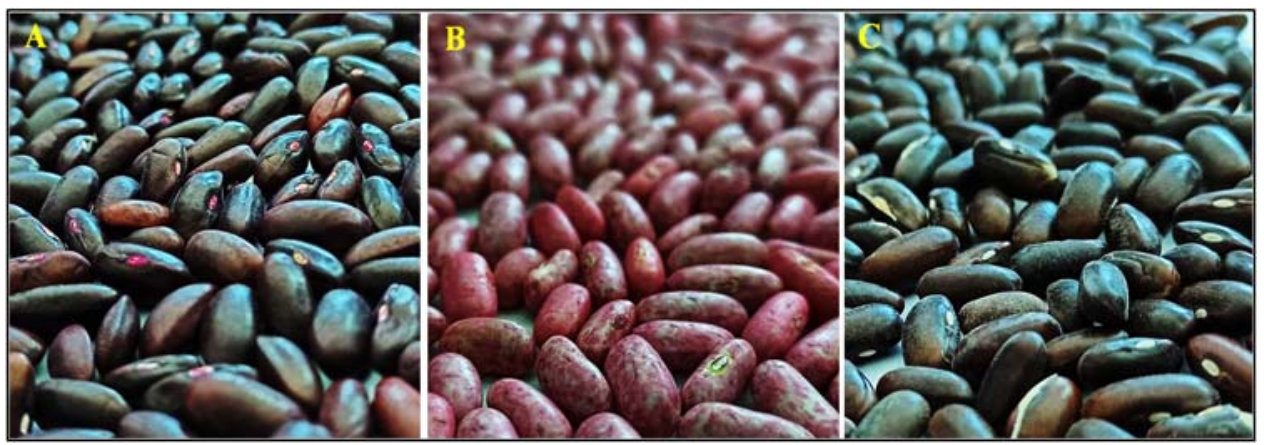

Figure 1 - Seeds of the different varieties of Phaseolus vulgaris used in the experiment: (A) Djedida, (B) Nelson and (C) Jalila

\section{Experimental design and treatments}

The experiments were laid out in a randomized complete block design with a split plot arrangement and replicated four times for each treatment (Fig. 2, Fig. 3). The fertilizer formed the main plots and the common bean varieties the subplots, each measuring $(4 \times 3 \mathrm{~m})$ with a $0.7 \mathrm{~m}$ alley between the plots and blocks, to minimize inter-plot interference. The fertilization factor consisted of two levels: fertilized (0.4 kg fertilizer/plot) and unfertilized ( $0 \mathrm{~kg}$ fertilizer/plot). The nitrogen fertilizer was added twice: before the flowering stage (50 days after sowing) and before the fruiting stage (70 days after sowing) by one week. Control plots did not receive any of the nitrogen source treatments. The vegetative period (40 days from sowing) did not receive fertilization.

Land preparation was carried out manually at the beginning of September, in two operations: plowing and harrowing. After preparing the soil, two seeds were placed in the furrows at the recommended spacing of $(30 \times 20) \mathrm{cm}$ with a density of 120 seeds per plot (30 seeds $\times 4$ lines). During the whole experiment, the plants did not receive any herbicide, pesticide or insecticide treatment. Weeds were monitored and removed manually. It should be noted that no attack of biotic origin was reported during this study, except a 5\% contamination by aphids, which colonized some plants in a single plot of the Nelson variety.

A model for drip irrigation system was used for the reasons that: fertilizer and nutrient loss is minimized, due to a localized application and reduced leaching, water application efficiency is high if managed correctly and field leveling is not necessary. The frequency of irrigation during the whole experiment was every 3-4 days.

\section{Determination of growth kinetics}

For the three varieties of common bean, the growth kinetics concerned the three main life stages of the plants viz. vegetative, flowering and fruiting. At each complete achievement of the growth period, plant dry biomass, shoot and root length and the number of secondary roots 


\section{L.M. MANSOURI, A. KHELOUFI, R. BELATRECHE, N. HELEILI, Z.F. BOUKHATEM}

were assessed. The total number of samples used was of 240 (10 plants $\times 4$ plots $\times$ 2 treatments $\times 3$ growth stages). Plants have been carefully dug up with a shovel on moist soil to avoid an abrupt uprooting. The plants were oven-dried at $70^{\circ} \mathrm{C}$, for $48 \mathrm{~h}$, for dry weight determination. It should be noted that the plant dry biomass was weighed without the flowers at the flowering stage and without the pods at the fruiting stage.

\section{Determination of some yield components}

The number of flowers per plant was determined in situ when a general flowering was reached in the three varieties and this at 60 days after sowing. Harvesting, at the end of the fruiting phase, was carried out 95 days after sowing, when signs of maturity were observed (yellowing of the leaves and drying of the pods). Ten plants were randomly selected from each plot. Soil was carefully washed from the roots. The nodules were picked from the roots and their numbers recorded for each plant. The number of pods and seeds per plant was also evaluated. Donald (1962) defined Harvest index (\%) as the ratio between dry weight of grains and the weight of total dry matter at maturity.

\section{Statistical analysis}

The results for each variable were expressed as mean \pm standard deviation $( \pm \mathrm{SD})$. All the data were subjected to oneway and two-way analysis of variance (ANOVA) and Duncan's multiple range test $(p<0.05)$ using SAS (Statistical Analysis System), version 9.0 (2002) software.

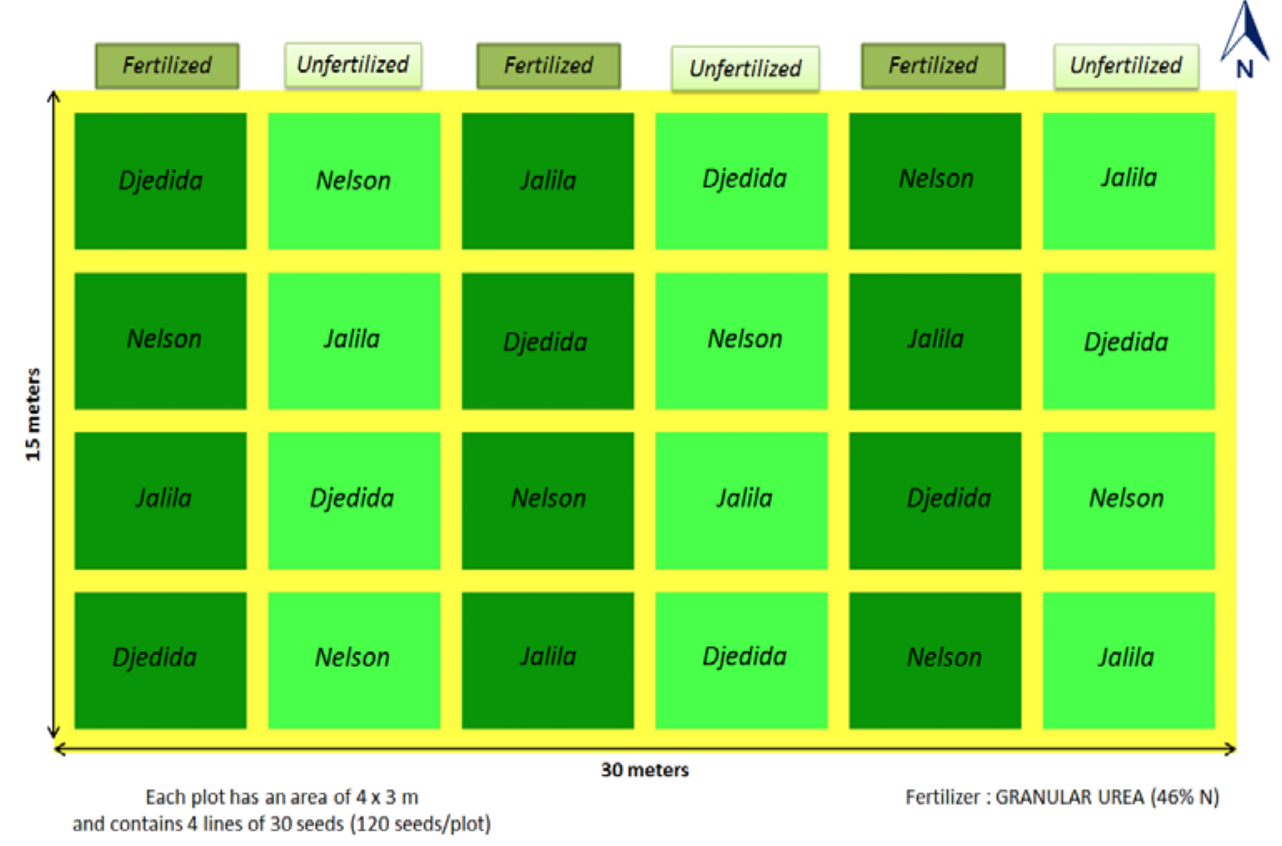

Figure 2 - Experimental design and treatments:

(3 varieties of Phaseolus vulgaris $\times 2$ levels of fertilization $\times 4$ replicates) 

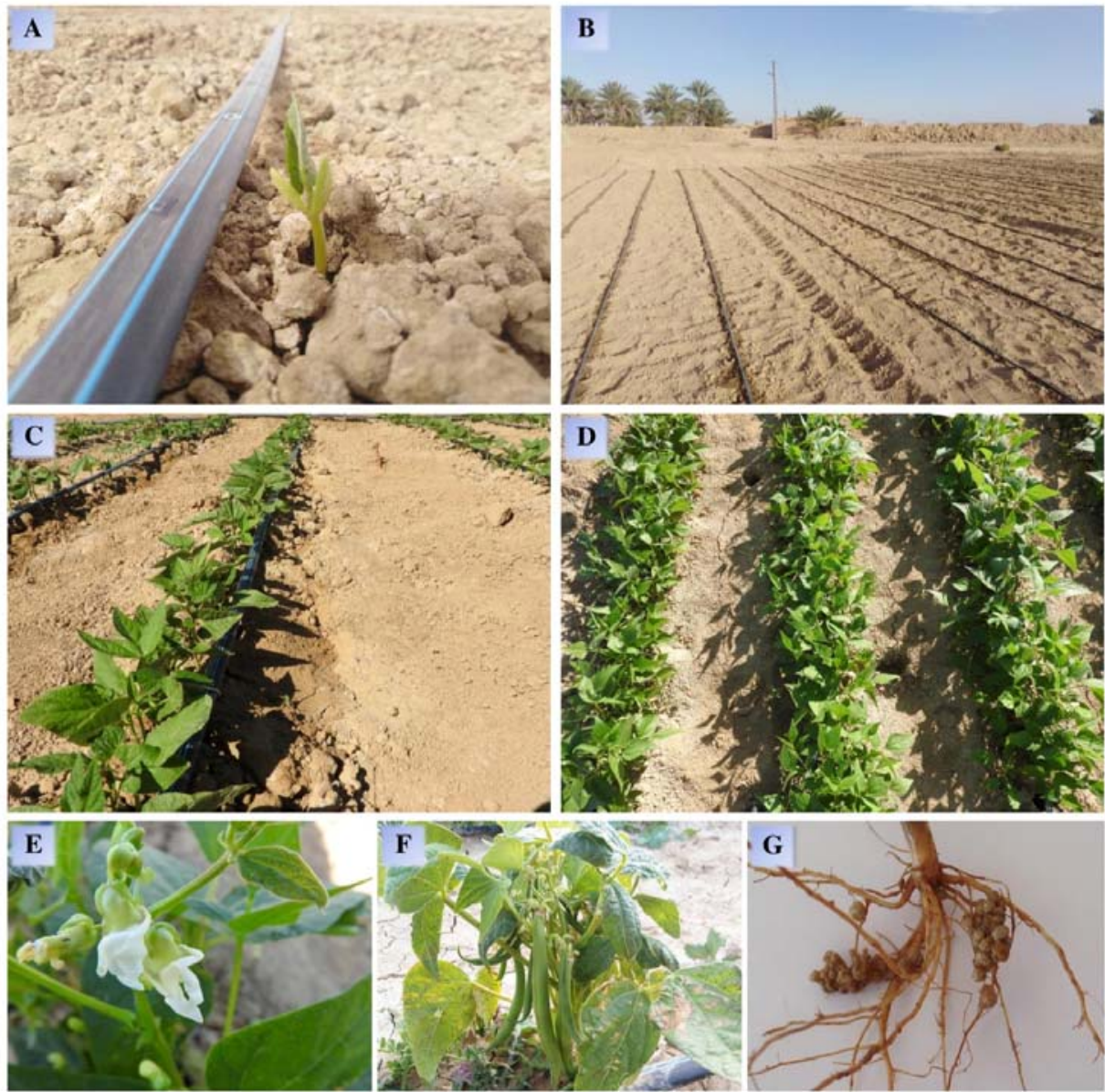

Figure 3 - General overview of the experimental set-up and the different stages of bean development in Aïn Naga (Biskra, Algeria): $(A)$ seedling emergence, $(B)$ Model of Drip irrigation, $(C)$ Vegetative phase, $(D, E)$ Flowering phase, (F) Fruiting phase and (G) Nodules appearance

\section{RESULTS AND DISCUSSION}

\section{Effect of $\mathbf{N}$ fertilization on developmental kinetics}

According to Table 3, the effect of the factors (fertilization $\times$ time $\times$ variety) was significant on total dry biomass $(p<0.0001)$, shoot length $(p<0.0001)$, root length $(p<0.0001)$, and the number of secondary root $(p=0.0143)$. On the other hand, a very marked increase in all the variables studied was observed over time (stages of development) and this in the three varieties. However, this increase differs from a treatment to another (Table 3). Furthermore, $\mathrm{N}$ fertilization has no relation with 


\section{L.M. MANSOURI, A. KHELOUFI, R. BELATRECHE, N. HELEILI, Z.F. BOUKHATEM}

phonological traits (Swiader et al., 1994; Xu et al., 2001; Dumka et al., 2004). Indeed, the three varieties of common bean, whether treated or not, started flowering and fruiting simultaneously.

Table 3 - Effect of variety, growth stage and treatment on some growth parameters in Phaseolus vulgaris from the arid region of Aïn Naga (Biskra, Algeria) $(n=40)$

\begin{tabular}{|c|c|c|c|c|c|c|}
\hline Varieties & $\begin{array}{l}\text { Growth } \\
\text { Stage }\end{array}$ & Fertilization & $\begin{array}{l}\text { Plant dry } \\
\text { biomass } \\
\text { (g) }\end{array}$ & $\begin{array}{l}\text { Shoot } \\
\text { length } \\
(\mathrm{cm})\end{array}$ & $\begin{array}{l}\text { Root } \\
\text { length } \\
(\mathrm{cm})\end{array}$ & $\begin{array}{c}\text { Secondary } \\
\text { roots } \\
\text { number }\end{array}$ \\
\hline \multirow{6}{*}{ Djedida } & \multirow{2}{*}{ VEG } & Fertilized & $\begin{array}{l}2.52 \pm \\
0.64^{\mathrm{a}}\end{array}$ & $\begin{array}{l}11.7 \pm \\
0.29^{\mathrm{a}}\end{array}$ & $\begin{array}{l}8.11 \pm \\
1.20^{\mathrm{a}}\end{array}$ & $7.40 \pm 0.93^{a}$ \\
\hline & & Unfertilized & $\begin{array}{l}2.52 \pm \\
0.64^{\mathrm{a}}\end{array}$ & $\begin{array}{c}11.7 \pm \\
0.29^{\mathrm{a}} \\
\end{array}$ & $\begin{array}{l}8.11 \pm \\
1.20^{\mathrm{a}}\end{array}$ & $7.40 \pm 0.93^{a}$ \\
\hline & \multirow[b]{2}{*}{ FLO } & Fertilized & $\begin{array}{l}4.97 \pm \\
0.12^{\mathrm{a}}\end{array}$ & $\begin{array}{l}18.9 \pm \\
3.66^{\mathrm{a}}\end{array}$ & $\begin{array}{l}12.5 \pm \\
1.60^{\mathrm{b}}\end{array}$ & $6.85 \pm 1.29^{b}$ \\
\hline & & Unfertilized & $\begin{array}{l}4.92 \pm \\
0.12^{\mathrm{a}}\end{array}$ & $\begin{array}{l}19.5 \pm \\
2.49^{\mathrm{a}}\end{array}$ & $\begin{array}{l}14.5 \pm \\
2.63^{\mathrm{a}}\end{array}$ & $8.35 \pm 1.44^{a}$ \\
\hline & \multirow[b]{2}{*}{ FRU } & Fertilized & $\begin{array}{l}5.68 \pm \\
0.11^{a}\end{array}$ & $\begin{array}{l}21.9 \pm \\
2.48^{\mathrm{a}}\end{array}$ & $\begin{array}{l}13.2 \pm \\
2.85^{\mathrm{a}}\end{array}$ & $7.85 \pm 1.96^{b}$ \\
\hline & & Unfertilized & $\begin{array}{l}4.75 \pm \\
0.11^{\mathrm{b}}\end{array}$ & $\begin{array}{l}20.9 \pm \\
2.87^{\mathrm{a}}\end{array}$ & $\begin{array}{l}13.6 \pm \\
2.54^{\mathrm{a}}\end{array}$ & $9.10 \pm 2.31^{a}$ \\
\hline \multirow{6}{*}{ Nelson } & \multirow{2}{*}{ VEG } & Fertilized & $\begin{array}{l}1.46 \pm \\
0.12^{\mathrm{a}}\end{array}$ & $\begin{array}{l}17.2 \pm \\
1.90^{\mathrm{a}}\end{array}$ & $\begin{array}{l}10.6 \pm \\
2.09^{\mathrm{a}}\end{array}$ & $6.70 \pm 1.64^{a}$ \\
\hline & & Unfertilized & $\begin{array}{l}1.46 \pm \\
0.12^{\mathrm{a}}\end{array}$ & $\begin{array}{c}17.2 \pm \\
1.90^{\mathrm{a}} \\
\end{array}$ & $\begin{array}{l}10.6 \pm \\
2.09^{\mathrm{a}} \\
\end{array}$ & $6.70 \pm 1.64^{\mathrm{a}}$ \\
\hline & \multirow{2}{*}{ FLO } & Fertilized & $\begin{array}{l}5.13 \pm \\
1.50^{\mathrm{a}}\end{array}$ & $\begin{array}{l}19.8 \pm \\
1.57^{\mathrm{a}}\end{array}$ & $\begin{array}{l}12.1 \pm \\
1.21^{\mathrm{a}}\end{array}$ & $7.20 \pm 2.23^{a}$ \\
\hline & & Unfertilized & $\begin{array}{l}3.29 \pm \\
0.76^{\mathrm{b}}\end{array}$ & $\begin{array}{l}18.3 \pm \\
3.54^{\mathrm{b}}\end{array}$ & $\begin{array}{l}12.6 \pm \\
1.34^{\mathrm{a}}\end{array}$ & $6.70 \pm 2.64^{a}$ \\
\hline & \multirow{2}{*}{ FRU } & Fertilized & $\begin{array}{l}4.98 \pm \\
1.07^{\mathrm{a}}\end{array}$ & $\begin{array}{l}22.6 \pm \\
6.10^{\mathrm{a}}\end{array}$ & $\begin{array}{l}12.3 \pm \\
1.63^{b}\end{array}$ & $7.40 \pm 2.92^{\mathrm{a}}$ \\
\hline & & Unfertilized & $\begin{array}{l}4.69 \pm \\
1.22^{\mathrm{a}}\end{array}$ & $\begin{array}{l}20.5 \pm \\
3.35^{\mathrm{a}}\end{array}$ & $\begin{array}{l}15.7 \pm \\
4.52^{\mathrm{a}}\end{array}$ & $7.65 \pm 1.67^{a}$ \\
\hline \multirow{6}{*}{ Jalila } & \multirow[b]{2}{*}{ VEG } & Fertilized & $\begin{array}{l}1.55 \pm \\
0.11^{\mathrm{a}}\end{array}$ & $\begin{array}{l}13.1 \pm \\
1.97^{\mathrm{a}}\end{array}$ & $\begin{array}{l}10.3 \pm \\
1.59^{\mathrm{a}}\end{array}$ & $5.70 \pm 1.81^{a}$ \\
\hline & & Unfertilized & $\begin{array}{l}1.55 \pm \\
0.11^{\mathrm{a}}\end{array}$ & $\begin{array}{l}13.1 \pm \\
1.97^{\mathrm{a}}\end{array}$ & $\begin{array}{l}10.3 \pm \\
1.59^{\mathrm{a}}\end{array}$ & $5.70 \pm 1.81^{a}$ \\
\hline & \multirow{2}{*}{ FLO } & Fertilized & $\begin{array}{l}4.69 \pm \\
1.60^{\mathrm{a}}\end{array}$ & $\begin{array}{l}18.9 \pm \\
2.12^{\mathrm{a}}\end{array}$ & $\begin{array}{l}11.5 \pm \\
1.47^{\mathrm{b}}\end{array}$ & $6.60 \pm 2.13^{\mathrm{a}}$ \\
\hline & & Unfertilized & $\begin{array}{l}4.59 \pm \\
1.14^{\mathrm{a}}\end{array}$ & $\begin{array}{l}17.3 \pm \\
2.66^{\mathrm{b}}\end{array}$ & $\begin{array}{l}12.6 \pm \\
1.69^{\mathrm{a}}\end{array}$ & $6.20 \pm 1.77^{a}$ \\
\hline & \multirow{2}{*}{ FRU } & Fertilized & $\begin{array}{l}5.55 \pm \\
1.25^{\mathrm{a}}\end{array}$ & $\begin{array}{l}23.2 \pm \\
4.87^{\mathrm{a}}\end{array}$ & $\begin{array}{l}12.0 \pm \\
2.70^{\mathrm{b}}\end{array}$ & $6.20 \pm 1.68^{b}$ \\
\hline & & Unfertilized & $\begin{array}{l}4.40 \pm \\
0.88^{\mathrm{b}}\end{array}$ & $\begin{array}{l}18.9 \pm \\
3.67^{\mathrm{b}}\end{array}$ & $\begin{array}{l}13.7 \pm \\
2.67^{\mathrm{a}}\end{array}$ & $7.05 \pm 1.61^{a}$ \\
\hline \multicolumn{2}{|c|}{$\begin{array}{l}\text { F of Fisher (VAR } \\
\text { Probability (VAR) }\end{array}$} & $\begin{array}{l}\text { S×FERT) } \\
\text { S×FERT) }\end{array}$ & $\begin{aligned} & 14.95 \\
< & 0.0001\end{aligned}$ & $\begin{aligned} & 6.27 \\
< & 0.0001\end{aligned}$ & $\begin{aligned} & 7.52 \\
< & 0.0001\end{aligned}$ & $\begin{array}{c}3.15 \\
0.0143\end{array}$ \\
\hline
\end{tabular}

For each growth stage, the same alphabet letters along the column indicates no significance difference (Duncan Multiple Range Test). VEG: vegetative; FLO: flowering; FRU: fruiting; VAR: variety; GS: growth stage; FERT: fertilization. 
Dry matter accumulation into plant varied according to the $\mathrm{N}$ levels and the growing period. Nitrogen fertilization was able to increase the total dry biomass of plants at the fruiting stage of the Djedida and Jalila varieties by $16 \%$ and $20 \%$, respectively, compared to the control (non-fertilized plants). However, the effect of fertilization on the Nelson variety was only significant at the flowering stage, recording an increase of 35\%, compared to the control (Table 3). Dry matter production is directly related to $\mathrm{N}$ supply. When $\mathrm{N}$ supply is low, there is lower production of dry matter, especially in leaves, which affects the production of photo-assimilates and distribution of assimilates to the reproductive organs (Dordas et al., 2008). One of the objectives of the present study was to determine how $\mathrm{N}$ application can affect dry matter accumulation in common bean, and we noted a significant effect on this characteristic. Dry matter accumulation can be affected by cultivar and prevailing growth conditions (Papakosta et al., 1991; Seppänen et al., 2018). $\mathrm{N}$ is one of the most important nutrients for plant growth; it affects dry matter accumulation and partitioning in many legume species (Guinet et al., 2018).

For the shoot length, the effect of fertilization was much more expressed in the Jalila variety, at the flowering and fruiting stages, with an improvement of $8 \%$ and $18 \%$, respectively. The effect of fertilization was also observed in the Nelson variety, with an improvement of $8 \%$, compared to the control, at the flowering stage, which is similar to that obtained by the Jalila variety. However, no effect of fertilization was observed in the Djedida variety (Table 3). These variations are related to differences in the genetic potential, growth habit and other intrinsic characteristics of each cultivar (Beebe et al., 2013; Inostroza et al., 2015).

For the roots, fertilization had a negative effect on growth in length in the three varieties studied, but at different stages of development. Indeed, the length growth of the roots at the flowering stage in the varieties Djedida and Jalila was delayed by $16 \%$ and $10 \%$, respectively. At the fruiting stage, this same variable was delayed in Nelson and Jalila with $28 \%$ and $14 \%$, respectively, compared to the non-fertilized plants (Table 3). Kohls and Baker (1989) reported that $\mathrm{N}$ fertilization reduces the number of secondary roots and root hairs and thus inhibits nodulation in actinorhizal plants. Using $P$. sativum, $V$. faba, $V$. sinensis and $P$. vulgaris as study materials, Wahab et al. (1996) found that nitrate-nitrogen suppresses root hair formation and also reduce secondary roots number and, thus reducing Rhizobium infection and the nodulation of root. Also, Costa et al. (2013) reported that root length and root surface area were increased, under intermediate $\mathrm{N}$ levels, and that root growth was reduced, under higher fertilization levels. 
The effect of fertilization was also negative on the number of secondary roots. This was observed in the variety Djedida, at the flowering stage, with a decrease of $20 \%$, and at the fruiting stage, with $16 \%$ decrease, compared to the control (Table 3). This effect has also been indicated in plants of the Jalila variety, but only at the fruiting stage, with a $14 \%$ reduction, compared to unfertilized plants. On the other hand, no effect of fertilization was observed in the variety Nelson on the number of secondary roots and this at the two development phases where nitrogen fertilization was applied (Table 3). Soil fertility and rhizosphere organisms have been shown significantly to alter root growth and architecture. Wiersum (1958) showed that high concentrations of nitrogen may stimulate root length and the number of primary roots, while phosphate deficiency can reduce both root length and the number of secondary and tertiary roots, without altering the number of primary roots (Bowen and Rovira, 1999).

\section{Combined effect of varieties and fertilization on some yield parameters}

According to Table 4, the fertilizer-variety interaction significantly influences the number of flowers per plant $(p<0.0001)$, the number of pods per plant $(p<0.0001)$, the number of seeds per plant ( $p<0.0001$ ), the number of nodules per plant $(p<0.0001)$, seeds dry weight $(p<0.0001)$ and the Harvest index $(p<0.0001)$.

Nitrogen fertilizer application before inflorescence initiation is well known to increase flower number. The highest number of flowers was recorded in the fertilized plants and this among all the varieties studied. The increase is about $30 \%, 50 \%$ and $16 \%$, respectively, in the variety Nelson, Jalila and Djedida, compared to the control plants (Table 4).

Monti et al. (2016) indicated that low $\mathrm{N}$ availability causes reduction in leaf $\mathrm{N}$, reduced number of flowers, low fruit set and yield.

The number of pods per plant was also influenced by fertilization in the three varieties. This variable was improved by $18 \%, 17 \%$ and $33 \%$, respectively, in Djedida, Nelson and Jalila, compared to non-fertilized plants (Table 4). Blair et al. (2009) noted that common bean varieties behave very differently when compared to soil fertility. Indeed, they observed that there were varieties that expressed their genetic potential only on a fertile environment.

According to Table 4, the number of seeds per plant was improved by nitrogen fertilization in the Nelson and Jalila varieties, with percentages of $12 \%$ and $40 \%$, respectively. However, the Djedida variety was not influenced by the fertilizer supply for this same variable by recording similar values of 32 seeds/plant and this in both fertilized and unfertilized plants. Seed yield has been observed to be one of the most stable morphological characteristics 
of many plant species (Chmielewski and Ruit, 2002).

Moreover, the total dry weight of seeds was only affected by fertilization in the Jalila variety. Once more, the variety Djedida seems not to be affected by fertilization for this variable, recording an average of $4 \mathrm{~g}$. This value is the highest compared to the other varieties with a ratio of $114 \%$ higher than the Nelson variety. For the Harvest index, only the varieties Djedida and Jalila seem to be affected by fertilization. The effect of fertilization is positive and seems to increase the $\mathrm{H}$ index by $18 \%$ in Djedida and by $20 \%$ in Jalila, compared to non-fertilized plants (Table 4). No significant effect was observed in the Nelson variety, which records the lowest values with an average of $35 \% \mathrm{H}$ index under both treatments (Table 4). This intervarietal variation in common bean yield could be due to the genetic heritage of the different varieties used by favoring or disadvantaging one or the other variety used in the edaphoclimatic conditions of the environment.

Table 4 - Combined effects of varieties and fertilization on the number of flowers, pods, seeds, nodules, seed weight and Harvest index per plant of Phaseolus vulgaris at flowering and fruiting stage $(n=40)$

\begin{tabular}{|c|c|c|c|c|c|c|c|}
\hline \multirow{2}{*}{ Varieties } & \multirow{2}{*}{ Fertilization } & \multicolumn{4}{|c|}{ Number per plant } & \multirow{2}{*}{$\begin{array}{c}\text { Seeds } \\
\text { dry } \\
\text { weight } \\
\text { (g) }\end{array}$} & \multirow{2}{*}{$\begin{array}{c}\text { HI (\%) } \\
\text { (per } \\
\text { plant) }\end{array}$} \\
\hline & & Flowers & Pods & Seeds & Nodules & & \\
\hline \multirow{2}{*}{ Djedida } & Fertilized & $\begin{array}{r}23.2 \\
\pm 4.29^{b} \\
\end{array}$ & $\begin{array}{c}11.7 \\
\pm 3.17^{\mathrm{a}} \\
\end{array}$ & $\begin{array}{c}32.5 \\
\pm 6.67^{\mathrm{a}} \\
\end{array}$ & $\begin{array}{c}1.60 \\
\pm 1.21^{\mathrm{d}} \\
\end{array}$ & $\begin{array}{c}4.09 \\
\pm 1.25^{\mathrm{a}} \\
\end{array}$ & $\begin{array}{r}88.6 \\
\pm 9.31^{\mathrm{a}} \\
\end{array}$ \\
\hline & Unfertilized & $\begin{array}{r}19.4 \\
\pm 2.18^{\mathrm{c}} \\
\end{array}$ & $\begin{array}{r}9.60 \\
\pm 3.68^{\mathrm{bc}} \\
\end{array}$ & $\begin{array}{r}32.5 \\
\pm 12.6^{a} \\
\end{array}$ & $\begin{array}{r}6.80 \\
\pm 2.01^{\mathrm{b}} \\
\end{array}$ & $\begin{array}{r}4.16 \\
\pm 1.08^{\mathrm{a}} \\
\end{array}$ & $\begin{array}{r}72.8 \\
\pm 9.43^{b} \\
\end{array}$ \\
\hline \multirow{2}{*}{ Nelson } & Fertilized & $\begin{array}{r}28.2 \\
\pm 9.31^{a} \\
\end{array}$ & $\begin{array}{c}10.6 \\
\pm 2.22^{\mathrm{ab}} \\
\end{array}$ & $\begin{array}{c}15.7 \\
\pm 4.05^{\mathrm{b}} \\
\end{array}$ & $\begin{array}{r}3.80 \\
\pm 2.72^{\mathrm{c}} \\
\end{array}$ & $\begin{array}{c}1.91 \\
\pm 1.02^{\mathrm{c}} \\
\end{array}$ & $\begin{array}{r}36.8 \\
\pm 12.1^{d} \\
\end{array}$ \\
\hline & Unfertilized & $\begin{array}{c}19.7 \\
\pm 7.61^{\mathrm{c}} \\
\end{array}$ & $\begin{array}{r}8.80 \\
\pm 1.68^{\mathrm{c}} \\
\end{array}$ & $\begin{array}{c}13.8 \\
\pm 4.04^{b}\end{array}$ & $\begin{array}{c}13.4 \\
\pm 4.51^{\mathrm{a}} \\
\end{array}$ & $\begin{array}{c}1.54 \\
\pm 0.47^{\mathrm{c}} \\
\end{array}$ & $\begin{array}{c}33.1 \\
\pm 6.04^{d} \\
\end{array}$ \\
\hline \multirow{2}{*}{ Jalila } & Fertilized & $\begin{array}{r}27.1 \\
\pm 7.44^{\mathrm{a}} \\
\end{array}$ & $\begin{array}{r}9.40 \\
\pm 1.93^{c}\end{array}$ & $\begin{array}{c}29.4 \\
\pm 7.80^{\mathrm{a}}\end{array}$ & $\begin{array}{r}0.80 \\
\pm 1.55^{d}\end{array}$ & $\begin{array}{r}3.44 \\
\pm 1.42^{\mathrm{b}}\end{array}$ & $\begin{array}{r}71.8 \\
\pm 11.2^{b}\end{array}$ \\
\hline & Unfertilized & $\begin{array}{r}13.7 \\
\pm 5.38^{d} \\
\end{array}$ & $\begin{array}{r}6.25 \\
\pm 2.16^{\mathrm{d}} \\
\end{array}$ & $\begin{array}{c}17.5 \\
\pm 9.70^{b} \\
\end{array}$ & $\begin{array}{r}3.50 \\
\pm 2.36^{\mathrm{c}} \\
\end{array}$ & $\begin{array}{r}4.24 \\
\pm 2.33^{\mathrm{a}} \\
\end{array}$ & $\begin{array}{c}59.9 \\
\pm 13.1^{\mathrm{c}} \\
\end{array}$ \\
\hline \multicolumn{2}{|c|}{$\begin{array}{l}\text { F of Fisher } \\
(V A R \times F E R T)\end{array}$} & 27.7 & 20.5 & 48.3 & 124.1 & 30.4 & 110.1 \\
\hline \multicolumn{2}{|c|}{$\begin{array}{l}\text { Probability } \\
\text { (VAR×FERT) }\end{array}$} & $\begin{array}{c}< \\
0.0001\end{array}$ & $\begin{array}{c}< \\
0.0001\end{array}$ & $\begin{array}{c}< \\
0.0001\end{array}$ & $\begin{array}{c}< \\
0.0001\end{array}$ & $\begin{array}{c}< \\
0.0001\end{array}$ & $\begin{array}{c}< \\
0.0001\end{array}$ \\
\hline
\end{tabular}

The same alphabet letters along the column indicates no significance difference (Duncan Multiple Range Test). VAR: variety; FERT: fertilization

This finding was also showed by Remans et al. (2008). Indeed, they not only found that, different genotypes could induce highly significant differences in yield, but also, the yield of the same genotype was significantly influenced by the environment. This difference in yield 
between fertilized and unfertilized plots can be explained by the fact that common bean productivity is greatly influenced by soil fertility (Fageria and Baligar, 1997; Fageria and Baligar, 2003; Jansa et al., 2011).

The nitrogen nutrition of the common bean is accomplished by two complementary processes during the plant growth cycle: either by assimilation of mineral nitrogen from the soil, or by symbiotic fixation of atmospheric nitrogen through the formation of root nodules (Unkovich and Pate, 2000).

The number of nodules per plant is the variable most affected by fertilization. This number was higher in the non-fertilized plants and this in the three varieties of common bean studied.

The classification, according to the values obtained, is Nelson > Djedida > Jalila. This number was higher by $253 \%, 325 \%$ and $338 \%$, respectively, in Nelson, Djedida and Jalila, compared to the values recorded in the fertilized plants for these same varieties (Table 4). Inhibitory effects of added nitrogen fertilizer to nodulation and nitrogen fixation have been reported for several legumes: Glycine max (Bezdicek et al., 1974); Trifolium subterraneum (Chambers et al., 1980) Vicia faba (Wahab and Abd-Alla, 1995); Gliricidia sepium (Thomas et al., 2000); Cicer arietinum (Anderson et al., 2004) and Phaseolus vulgaris (Kawaka et al., 2018). Kakraliya et al. (2018) observed that the application of $\mathrm{N}$ fertilizer caused nodule degeneration on French beans.

In addition, Drevon et al. (2015) reported that high $\mathrm{N}$ levels inhibited early cell divisions in the cortex, which will inhibit nodulation.

According to Otieno et al. (2009), fertilizer application significantly reduced the number of nodules per plant in lablab (Lablab purpureus) and common bean, but had no significant effect on green gram and lima bean. Nitrogen nutrition of legumes is firstly ensured by the reduction of $\mathrm{NO}_{3}{ }^{-}$from the soil, before the symbiotic fixation takes over (Valentine et al., 2018).

It should be shown that soil characteristics can play an important part for a best yield and productivity. As it was indicated for soil analysis, our experimental site is silty and very calcareous, with $53.1 \%$ of total $\mathrm{CaCO}_{3}$, with $7.7 \mathrm{pH}$. Indeed, calcareous soils are identified by the presence of the mineral calcium carbonate $\left(\mathrm{CaCO}_{3}\right.$ or lime).

The $\mathrm{pH}$ of these soils is usually above 7 and may be as high as 8.5 (Ceyhan et al., 2014). When these soils contain sodium carbonate, the $\mathrm{pH}$ may exceed 9. Yet these types of soils can be extremely productive for agricultural use when they are managed properly.

\section{CONCLUSION}

We can deduce that the varieties showing a large gap between fertilized and unfertilized plots would have the capacity to express their 
genetic potential on fertile soils. Varieties for which there is a small yield gap regardless of fertilization would be improved to produce better, even under unfavorable fertility conditions. Achieving a better yield of common bean first depended on the choice of variety. The Djedida and Jalila varieties gave the highest yield under nitrogen fertilization and this in the majority of the parameters studied. However, the Nelson variety has shown its ability to better nodulate in calcareous soil, expressing the highest number of nodules per plant without adding fertilizer. In addition, a highly significant difference in yield was noted between fertilized and unfertilized plots. According to our results, the percentage of improvement by $\mathrm{N}$ fertilization on one parameter or another does not exceed an average of $20 \%$, compared to the control. This rate could be important for very large agricultural area; however, we will recommend researches on the optimal amounts of $\mathrm{N}$ fertilizers, in order to decrease the impact of excess chemical fertilizers on the environment and health. Much more research on $\mathrm{N}_{2}$ fixation in common bean is also needed.

\section{REFERENCES}

Anderson, A., Baldock, J.A., Rogers, S.L., Bellotti, W. \& Gill, G. (2004). Influence of chlorsulfuron on rhizobial growth, nodule formation, and nitrogen fixation with chickpea. Aust.J.Agric.Res., 55(10): 10591070, DOI: 10.1071/AR03057
Baptista, A., Pinho, O., Pinto, E., Casal, S., Mota, C. \& Ferreira, I.M. (2017). Characterization of protein and fat composition of seeds from common beans (Phaseolus vulgaris L.), cowpea (Vigna unguiculata L. Walp) and bambara groundnuts (Vigna subterranea L. Verdc) from Mozambique. J. Food Meas. Charact., 11(2): 442-450, DOI: $10.1007 / \mathrm{s} 11$ 694-016-9412-2

Beebe, S., Rao, I., Blair, M. \& AcostaGallegos, J. (2013). Phenotyping common beans for adaptation to drought. Frontiers in physiology, 4: 35, DOI: 10.3389/fphys.2013.00035

Bezdicek, D.F., Mulford, R.F. \& Magee, B.H. (1974). Influence of organic nitrogen on soil nitrogen, nodulation, nitrogen fixation, and yield of soybeans. Soil Sci.Soc.Am.J., 38(2): 268-273, DOI: 10.2136/sssaj1974. 03615995003800020020x

Blair, M.W., Astudillo, C., Grusak, M.A., Graham, R. \& Beebe, S.E. (2009). Inheritance of seed iron and zinc concentrations in common bean (Phaseolus vulgaris L.). Mol. Breeding, 23(2): 197-207, DOI: 10.1007/s11032-008-9225-Z

Bokhorst, S., Kardol, P., Bellingham, P.J., Kooyman, R.M., Richardson, S.J., Schmidt, S. \& Wardle, D.A. (2017). Responses of communities of soil organisms and plants to soil aging at two contrasting long-term chronosequences. Soil Biol.Biochem., 106: 69-79, DOI: 10.1016/j.soilbio. 2016.12.014

Bowen, G.D. \& Rovira, A.D. (1999). The rhizosphere and its management to improve plant growth. Adv.Agron., 66: 1-102, DOI: 10.1016/S00652113(08)60425-3

Carranca C. (2013). Legumes: Properties and symbiosis. Symbiosis: Evolution, Biology and Ecological Effects (Eds. Camisão, AH y Pedroso, CC). Nova Science Publishers, New York, pp. 67-94.

Ceyhan, E., Kahraman, A., Avci, M.A. \& Dalgiç, H. (2014). Combining ability 
of bean genotypes estimated by line $x$ tester analysis under highlycalcareous soils. J.Anim. Plant Sci., 24(2): 579-584.

Chakraborty, A., Chakrabarti, K., Chakraborty, A. \& Ghosh, S. (2011). Effect of long-term fertilizers and manure application on microbial biomass and microbial activity of a tropical agricultural soil. Biol.Fert. Soils, 47(2): 227-233, DOI: 10.1007/ s00374-010-0509-1

Chambers, C.A., Smith, S.E. \& Smith, F.A. (1980). Effects of ammonium and nitrate ions on mycorrhizal infection, nodulation and growth of Trifolium subterraneum. New Phytol., 85(1): 47-62, DOI: 10.1111/j.14698137.1980.tb04447.x

Chmielewski, J.G. \& Ruit, S. (2002). Interrelationships among achene weight, orientation, and germination in the asters Doellingeria umbellata var. Umbellata var. Symphyotrichum novae-angliae and $S$. puniceum (Asteraceae). Bartonia, 61: 15-26.

Choze, R., Alcantara, G.B., Alves Filho, E.D.G., e Silva, L.M.A., Faria, J.C. \& Lião, L.M. (2013). Distinction between a transgenic and a conventional common bean genotype by $1 \mathrm{H}$ HR-MAS NMR. Food Chem., 141(3): 2841-2847, DOI: $\quad 10.1016 / j . f o o d c h e m .2013 .05$. 123

Costa, N.L., Moraes, A., Monteiro, A.L.G., Motta, A.C.V., Oliveira, R.A. \& Rodrigues, A.N.A. (2013). Forage productivity and morphogenesis of Axonopus aureus under different nitrogen fertilization rates. R.Bras. Zootec., 42(8): 541-548, DOI: 10. 1590/S1516-35982013000800002

Donald, C.M. (1962). In search of yield. J.Aust.Inst.Agric.Sci., 28, 171-178.

Dordas, C.A., Lithourgidis, A.S., Matsi, T. \& Barbayiannis, N. (2008). Application of liquid cattle manure and inorganic fertilizers affect dry matter, nitrogen accumulation, and partitioning in maize. Nutr.Cycl.
Agroecosys., 80(3): 283-296, DOI: 10.1007/s10705-007-9143-1

Drevon, J.J., Alkama, N., Bargaz, A., Rodiño, A.P., Sungthongwises, K. \& Zaman-Allah, M. (2015). The legume-rhizobia symbiosis. In: Grain Legumes, pp. 267-290, Springer, New York.

Dumka, D., Bednarz, C.W. \& Maw, B.W. (2004). Delayed initiation of fruiting as a mechanism of improved drought avoidance in cotton. Crop Sci., 44(2): 528-534.

Fageria, N.K. \& Baligar, V.C. (1997). Response of common bean, upland rice, corn, wheat, and soybean to soil fertility of an Oxisol. J. Plant Nutr., 20(10): 1279-1289, DOI: 10.1080/ 01904169709365335

Fageria, N.K. \& Baligar, V.C. (2003). Fertility management of tropical acid soils for sustainable crop production. In Handbook of soil acidity ( $Z$. Rengel, Ed.), pp. 359-385. Marcel Dekker, New York.

Fernández-Luqueño, F., Reyes-Varela, V., Martínez-Suárez, C., SalomónHernández, G., Yáñez-Meneses, J., Ceballos-Ramírez, J.M. \& Dendooven, L. (2010). Effect of different nitrogen sources on plant characteristics and yield of common bean (Phaseolus vulgaris L.). Bioresour.Technol., 101(1): 396-403, DOI: 10.1016/j.biortech.2009.07.058

Fustec, J., Lesuffleur, F., Mahieu, S. \& Cliquet, J.B. (2010). Nitrogen rhizodeposition of legumes. A review. Agron.Sustain.Dev., 30(1): 57-66, DOI: 10.1051/agro/2009 003

García-Garijo, A., Tejera, N.A., Lluch, C. \& Palma, F. (2014). Metabolic responses in root nodules of Phaseolus vulgaris and Vicia sativa exposed to the imazamox herbicide. Pestic.Biochem.Phys., 111: 19-23, DOI: 10.1016/j.pestbp.2014.04.005

Graham, P.H. (1981). Some problems of nodulation and symbiotic nitrogen fixation in Phaseolus vulgaris L.: a 
review. Field Crops Res., 4: 93-112, DOI: 10.1016/0378-4290(81)90060-5 Guinet, M., Nicolardot, B., Revellin, C., Durey, V., Carlsson, G. \& Voisin, A.S. (2018). Comparative effect of inorganic $\mathrm{N}$ on plant growth and $\mathrm{N}_{2}$ fixation of ten legume crops: towards a better understanding of the differential response among species. Plant Soil, 432(1-2): 207-227, DOI: 10.1007/s11104-018-3788-1

Inostroza, L., Acuña, H. \& Tapia, G. (2015). Relationships between phenotypic variation in osmotic adjustment, water-use efficiency, and drought tolerance of seven cultivars of Lotus corniculatus L. Chil.J.Agr. Res., 75(1): 3-12, DOI: 10.4067/ S0718-58392015000100001

Jansa, J., Bationo, A., Frossard, E. \& Rao, I.M. (2011). Options for improving plant nutrition to increase common bean productivity in Africa. In: Fighting poverty in Sub-Saharan Africa: the multiple roles of legumes in integrated soil fertility management, pp. 201-240, Springer, Dordrecht.

Jin, Z., Prasad, R., Shriver, J. \& Zhuang, Q. (2017). Crop model-and satellite imagery-based recommendation tool for variable rate $\mathrm{N}$ fertilizer application for the US Corn system. Precis.Agric., 18(5): 779-800, DOI: 10.1007/s11119-016-9488-z

Kakraliya, S.K., Singh, U., Bohra, A., Choudhary, K. K., Kumar, S., Meena, R.S. \& Jat, M.L. (2018). Nitrogen and legumes: a metaanalysis. In: Legumes for Soil Health and Sustainable Management, pp. 277-314, Springer, Singapore.

Kawaka, F., Dida, M., Opala, P., Ombori, O., Maingi, J., Amoding, A. \& Muoma, J. (2018). Effect of nitrogen sources on the yield of common bean (Phaseolus vulgaris) in western Kenya. J. Plant Nutr., 41(13): 16521661, DOI: 10.1080/01904167.2018. 1458870
Knapp, B.A., Ros, M. \& Insam, H. (2010). Do composts affect the soil microbial community? In: Microbes at work, pp. 271-291, Springer, Berlin, Heidelberg.

Kohls, S.J. \& Baker, D.D. (1989). Effects of substrate nitrate concentration on symbiotic nodule formation in actinorhizal plants. Plant Soil, 118(12): 171-179, DOI: $10.1007 / \mathrm{BF} 022$ 32804

Larney, F.J. \& Angers, D.A. (2012). The role of organic amendments in soil reclamation: a review. Canadian J. Soil Sci., 92(1): 19-38, DOI: 10.4141/cjss2010-064

Lemanceau, P., Maron, P.A., Mazurier, S., Mougel, C., Pivato, B., Plassart, P., Ranjard, L., Revellin, C., Tardy, V. \& Wipf, D. (2015). Understanding and managing soil biodiversity: a major challenge in agroecology. Agron.Sustain.Dev., 35(1): 67-81, DOI: $10.1007 / s 13593-014-0247-0$

Li, J., Cooper, J.M., Li, Y., Yang, X. \& Zhao, B. (2015). Soil microbial community structure and function are significantly affected by long-term organic and mineral fertilization regimes in the North China Plain. Appl. Soil Ecol., 96: 75-87, DOI: 10.1016/j.apsoil.2015.07.001

Liu, H., Zhang, C., Yang, J., Yu, N. \& Wang, E. (2018). Hormone modulation of legume-rhizobial symbiosis. Journal of Integrative Plant Biol., 60(8): 632-648, DOI: 10.1111/jipb.12653

Mansouri, L.M., Heleili, N., Boukhatem, Z.F. \& Kheloufi, A. (2019). Seed germination and radicle establishment related to type and level of salt in common bean (Phaseolus vulgaris L. var. Djedida). Cercet. Agron. in Moldova (Agronomical Research in Moldavia), 52(3): 262-277, DOI: 10.2478/cerce2019-0026

Monti, M., Pellicanò, A., Santonoceto, C., Preiti, G. \& Pristeri, A. (2016). Yield components and nitrogen use in cereal-pea intercrops in 


\section{L.M. MANSOURI, A. KHELOUFI, R. BELATRECHE, N. HELEILI, Z.F. BOUKHATEM}

Mediterranean environment. Field Crops Res., 196: 379-388, DOI: 10. 1016/j.fcr.2016.07.017

Nascente, A.S., Carvalho, M.D.C.S., Melo, L.C. \& Rosa, P.H. (2017). Nitrogen management effects on soil mineral nitrogen, plant nutrition and yield of super early cycle common bean genotypes. ActaSci.Agron., 39(3): 369-378, DOI: 10.4025/acta sciagron.v39i3.32781

Nassary, E.K., Baijukya, F. \& Ndakidemi, P.A. (2020). Productivity of intercropping with maize and common bean over five cropping seasons on smallholder farms of Tanzania. Eur.J.Agron., 113: 125964, DOI: 10.1016/j.eja.2019.12 5964

Osdaghi, E., Shams-Bakhsh, M., Alizadeh, A., Lak, M.R. \& Maleki, H.H. (2011). Induction of resistance in common bean by Rhizobium leguminosarum bv. phaseoli and decrease of common bacterial blight. Phytopathol.Mediterr., 50(1): 45-54.

Otieno, P., Muthomi, J., Chemining'wa, G. \& Nderitu, J. (2009). Nodulation and yield of food grain legumes. J.Biol.Sci., 9(4): 326-332.

Papakosta, D.K. \& Gagianas, A.A. (1991). Nitrogen and dry matter accumulation, remobilization, and losses for Mediterranean wheat during grain filling. Agron.., 83(5): 864-870, DOI: 10.2134/agronj1991. 00021962008300050018x

Remans, R., Ramaekers, L., Schelkens, S., Hernandez, G., Garcia, A., Reyes, J.L., Mendez, N., Toscano, V, Mulling,M., Galvez, L. \& Vanderleyden, J. (2008). Effect of Rhizobium-Azospirillum

coinoculation on nitrogen fixation and yield of two contrasting Phaseolus vulgaris L. genotypes cultivated across different environments in Cuba. Plant Soil, 312(1-2): 25-37, DOI: $10.1007 / \mathrm{s} 11104-008-9606-4$

Senyolo, M.P., Long, T.B., Blok, V. \& Omta, O. (2018). How the characteristics of innovations impact their adoption: An exploration of climate-smart agricultural innovations in South Africa. J.Clean.Prod., 172: 3825-3840, DOI: 10.1016/j.jclepro. 2017.06.019

Seppänen, M.M., Alitalo, V., Bäckström, H.K., Mäkiniemi, K., Jokela, V., Falghera-Winseman, L. \& Khazaei, H. (2018). Growth, freezing tolerance, and yield performance of alfalfa (Medicago sativa L.) cultivars grown under controlled and field conditions in northern latitudes. Can.J. Plant Sci., 98(5): 1109-1118, DOI: $10.1139 / C J P S-2017-0305$

Smethurst, P.J. (2010). Forest fertilization: trends in knowledge and practice compared to agriculture. Plant Soil, 335(1-2): 83-100, DOI: 10.1007/s11104-010-0316-3

Souza, R.D., Ambrosini, A. \& Passaglia, L.M. (2015). Plant growth-promoting bacteria as inoculants in agricultural soils. Genet.Mol.Biol., 38(4): 401419,k DOI: 10.1590/S1415-4757384 20150053

Swiader, J.M., Sipp, S.K. \& Brown, R.E. (1994). Pumpkin growth, flowering, and fruiting response to nitrogen and potassium sprinkler fertigation in sandy soil. J.Amer.Soc.Hort.Sci., 119(3): 414-419, DOI: 10.21273/ JASHS.119.3.414

Thomas, R.B., Bashkin, M.A. \& Richter, D.D. (2000). Nitrogen inhibition of nodulation and $\mathrm{N}_{2}$ fixation of $\mathrm{a}$ tropical $\mathrm{N}_{2}$-fixing tree (Gliricidia sepium) grown in elevated atmospheric $\mathrm{CO}_{2}$. New Phytol., 145(2): 233-243, DOI: 10.1046/j. 1469-8137.2000.00577.x

Turuko, M. \& Mohammed, A. (2014). Effect of different phosphorus fertilizer rates on growth, dry matter yield and yield components of common bean (Phaseolus vulgaris L.). World J.Agric. Res., 2(3): 88-92, DOI: 10.12691/wjar-2-3-1

Unkovich, M.J. \& Pate, J.S. (2000). An appraisal of recent field measurements of symbiotic $\mathrm{N}_{2}$ fixation by annual legumes. Field 


\section{PERFORMANCE OF COMMON BEAN UNDER NITROGEN FERTILIZATION}

Crops Res., 65(2-3): 211-228, DOI: 10.1016/S0378-4290(99)00088-X

Valentine, A.J., Benedito, V.A. \& Kang, Y. (2018). Legume nitrogen fixation and soil abiotic stress: from physiology to genomics and beyond. Annual Plant Reviews online, 207248, DOI: 10.1002/978111931299 4.apr0456

Wahab, A.A. \& Abd-Alla, M.H. (1995). The role of potassium fertilizer in nodulation and nitrogen fixation of faba bean (Vicia faba L.) plants under drought stress. Biol.Fert.Soils, 20(2), 147-150.

Wahab, A.A., Zahran, H.H. \& Abd-Alla, M.H. (1996). Root-hair infection and nodulation of four grain legumes as affected by the form and the application time of nitrogen fertilizer. Folia Microbiol., 41(4): 303-308.

Wiersum, L.K. (1958). Density of root branching as affected by substrate and separate ions. Acta Bot.Neerl., 7(2): 174-190.
Xu, G., Wolf, S. \& Kafkafi, U. (2001). Interactive effect of nutrient concentration and container volume on flowering, fruiting, and nutrient uptake of sweet pepper. J. Plant Nutr., 24(3): 479-501, DOI: 10.1081 /PLN-100104974

Yin, J., Deng, C.B., Wang, X.F., Chen, G.L., Mihucz, V.G., Xu, G.P. \& Deng, Q.C. (2019). Effects of longterm application of vinasse on physicochemical properties, heavy metals content and microbial diversity in sugarcane field soil. Sugar Tech, 21(1): 62-70.

Zhang, C., Liu, G., Xue, S. \& Wang, G. (2016). Soil bacterial community dynamics reflect changes in plant community and soil properties during the secondary succession of abandoned farmland in the Loess Plateau. Soil Biol.Biochem., 97: 4049, DOI: 10.1016/j.soilbio.2016.02. 013. 